\title{
Fishery Management for Crab Resources Using an Ecosystem Approach
}

\author{
Dwi Indah Widya Yanti ${ }^{1}$, Roger R. Tabalessy, ${ }^{2}$ Fanny Simatauw ${ }^{3}$, Irwanto ${ }^{4}$, Inayah ${ }^{5}$ \\ Management Aquatic Resources, Papua Christian University ${ }^{1,2}$, \\ Papua University ${ }^{3}$, \\ World Wild Fund (WWF) ${ }^{4,5}$ \\ \{indahwidyayanti83@gmail.com $\left.{ }^{1}\right\}$
}

\begin{abstract}
In general, the EAFM (Ecosystem Approach to Fisheries Management) is a method and indicator analysis that can be used effectively to determine the status or level of sustainability of area-based fisheries management. Mangrove crabs as a renewable biological resource need to be managed properly, because they are prone to depletion / extinction, or have a limited abundance, according to their carrying capacity. The purpose of this research is to conduct an assessment of the EAFM indicator for the Fish Resource Domain in shrimp fishery management in Bintuni Bay Regency. The method used in this research is observation and interview. Data were analyzed using Flag Modeling and Descriptive Analysis. The results of the assessment on the Fish Resource Domain indicate that the management of crab fisheries in Teluk Bintuni Regency is in good condition, with a mean value of 2.5.
\end{abstract}

Keyword : Management, Approach, Resource

\section{Introduction}

The area of Teluk Bintuni is one of the newly created districts in West Papua Province which was just ratified at the Plenary Meeting of the House of Representatives on November 12, 2002. It is located between the southern coast of Bird's Head and Onin Peninsula Beach, facing the Seram Sea off the west coast of Papua. Adjacent to the neck of a narrow mountain that connects Bird's Head with other areas in Papua Province. Geographically, the Bintuni Bay Regency area is between $1^{\circ} 57^{\prime} 50$ "South Latitude - $3^{\circ} 11^{\prime} 26^{\prime \prime}$ South Latitude and 1.9.32 ${ }^{\circ}$ $44^{\prime} 59$ "- $134^{\circ} 14^{\prime} 49^{\prime \prime}$ East Longitude and is located between the south shore of the bird's head and the coast of the peninsula. Onin overlooking the Seram sea off the west coast of Papua [1].

Mangrove crab resources as renewable biological resources need to be managed properly, because they are prone to depletion / extinction, or have a limited abundance, according to their carrying capacity. In addition, crab is also a common property which is prone to over fishing. Efforts to manage crab resources in the right and proper way are a must. At the same time, the issue of damage to fishery resources in these resources, such as over fishing. The size of mangrove crabs that can be caught has a carapace width of at least $15 \mathrm{~cm}$ and a weight of 300 grams [2]. 
Fishery management is an obligation as mandated by Law No. 45/2009. Naturally, fisheries system management cannot be separated from three inseparable dimensions, namely (1) dimensions of fishery resources and their ecosystems; (2) dimensions of fishery resource utilization for the socio-economic interests of the community; and (3) the dimensions of fisheries policy itself. In this context, fisheries management whose ultimate goal is to provide optimal socio-economic benefits for the community cannot be separated from the dynamics of the ecosystem which is a living medium for fish resources itself [3]. FAO (2003) defines the Ecosystem Approach to Fisheries (EAF) as "approach to ecosystem to move the fishery for balancing purpose - the purpose of society by taking into account knowledge and uncertainty about the components of biotic, abiotic and human of ecosystems - ecosystems. and their interactions and applying the approach to fisheries in integrated in bonds ecological ". Simply EAF as a concept of how to balance between socioeconomic objectives in fisheries management (the fishermen's welfare, justice utilization of fish resources, etc.) while considering the knowledge, information and uncertainty about the components of biotic, abiotic and human interaction in aquatic ecosystems through an integrated, comprehensive and sustainable fisheries management. EAFM implementation requires indicators that can be used as a monitoring and evaluation tool regarding the extent to which fisheries management has applied the principles of ecosystem-based management . The fisheries management approach in EAFM is to evaluate the ongoing fisheries management structure using indicator sets that are incorporated into the six EAFM domains (fish resources, habitat, fishing techniques, social, economic, and institutional) [4].

The paper aims to conduct an assessment of EAFM indicators in shrimp fishery management in Teluk Bintuni Regency. In addition to emphasizing the ecosystem approach, EAFM also consider aspects of community involvement so as to create an integrated fisheries management measures and sustainable while maintaining the state of the environment, and can be used for the development of marine fisheries in Indonesia in general and the region of Teluk Bintuni Regency. The specific objectives of this study are to:

a. Collect EAFM indicator data.

b. Know the fishery status of Crab.

c. Formulate sustainable fisheries management strategies.

\section{Methodology}

This paper use Observation and Interview methods.Observation, which is a process of systematic, logical, objective and rational observation and recording of various phenomena, both in actual situations and in artificial situations to achieve certain goals. Interview, which is an activity carried out to obtain information directly by revealing questions to the respondents. Meaningful face-to-face interviews between interviews with respondents, and activities are carried out orally.

The data analysis used in this research is Flag Modeling Analysis and Descriptive Analysis. Flag Modeling analysis is carried out using a multi-criteria analysis (MCA) approach in which a set of criteria is built as a basis for analysis of fisheries management area diversity seen from the ecosystem approach in fisheries management (EAFM) through the development of a composite index [5] with the following stages:

a. Determine the criteria for each indicator in each EAFM Domain.

b. Give a score for each indicator using a Likert Score Based on Ordinal 1, 2, and 3.

c. Determine the weight for each indicator. 
The value of each indicator in the Fish Resource Domain, Habitat and Ecosystem, Fishing Technology, Social, Economic and Institutional Analysis will then be analyzed using a simple composite analysis based on arithmetic mean which is then displayed in the form of a flag model as shown in the Table 1 below.

Table 1. Composite Index Value Classification and Flag Model Visualization

\begin{tabular}{cll}
\hline Score & Flag Model & Description \\
\hline 1 & Bad \\
2 & Moderate \\
3 & Good \\
\hline
\end{tabular}

\section{Results and Discussion}

\subsection{Fish Resourcers Domain}

The fish resource domain consists of six indicators that explain the management of crab resources in Bintuni Bay Regency from the aspect of fish resources. The six indicators consist of:

\section{a) Raw Catch Per Unit Effort (CPUE)}

Catch per unit effort (CPUE) is a ratio commonly used to eliminate temporal and regional trends in simple estimates of fish stock abundance. The "catch" portion of the measure may be expressed as the number or weight of the entire catch, a selected subset of the catch or a particular species in the catch. The "unit effort" portion of the rate usually refers to the time a uniformly designed and employed piece of fishing gear is deployed in the water [6].

Based on the USAID SEA Project Bintuni Bay Baseline Report in 2017, and WWF Enumerator data for 2018 and 2019, the average CPUE over the last 3 years is 159.16 (2017), 466.72 (2018) and 403.69 (2019). The factor of the number of fishermen and the number of trips also affects the increase in crab yields in Teluk Bintuni (Figure 1).

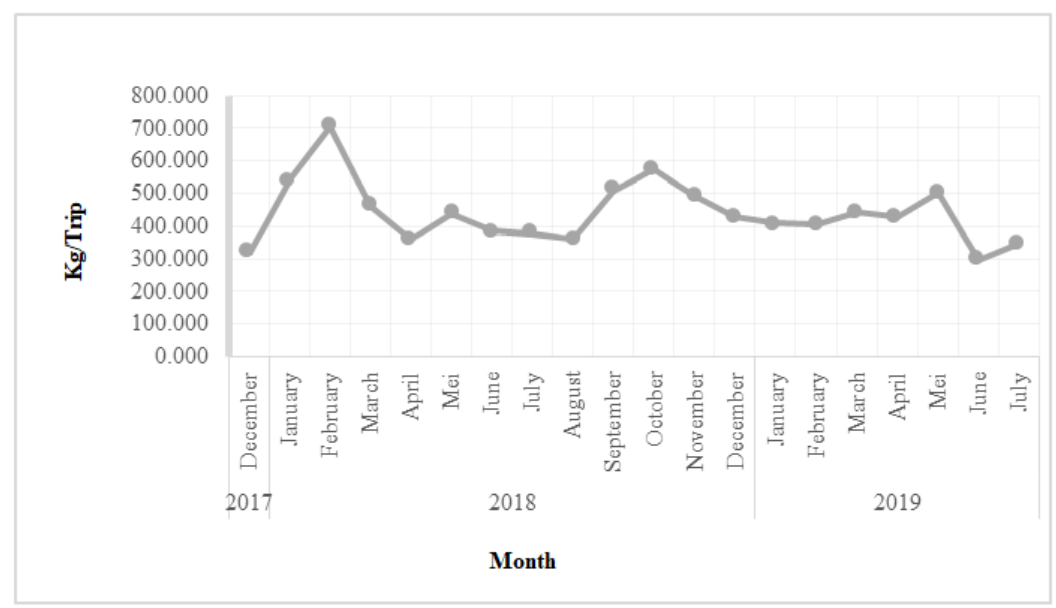


Fig. 1. Crab CPUE in 2017-2019

Based on Figure 1 above, there was a decrease in CPUE in 2019 but this decline was not too significant. The assumption of the decline in CPUE is due to a ban on crab fishing in Bintuni waters from the Wamesa tribe Manibuy, Maboro, Kemon) on 22 April-26 June 2019. Based on the crab species caught are Scylla traguebarica, Scylla olivacea and Scylla sp. The Standard Catch Per Unit Effort (CPUE) indicator is categorized as good and is given a score of 2 which is decreasing slightly (average decreases $<25 \%$ per year).

\section{b) Trends in Crab Size}

The crab measurement is based on the measurement of the total width. The total width was measured from the right side to the left, while the width of the kerapace was measured from the interior end of the head to the posterior end of the lower part of the carapace. From the measurement results of the sample, the width of the male crab carapace ranges from $12.43 \mathrm{~cm}$ $13.15 \mathrm{~cm}$ (weight ranges from 380.27 grams - 519.43 grams) and carapace widths range from $12.6 \mathrm{~cm}-13.41 \mathrm{~cm}$. weight ranges from 321.24 grams to 462.92 grams).

Regulation of the Minister of Marine and Fisheries of the Republic of Indonesia Number 56 of 2016 regulates that the conditions for catching mangrove crabs are that they are not in a state of laying eggs with a carapace width of more than $15 \mathrm{~cm}$ or a weight of more than 200 grams per head. The results of carapace measurements and crab weight can be seen in Figures 2 and 3. Based on Figures 2 and 3, they are categorized as moderate and given a score of 2, namely the trend of relatively fixed size.

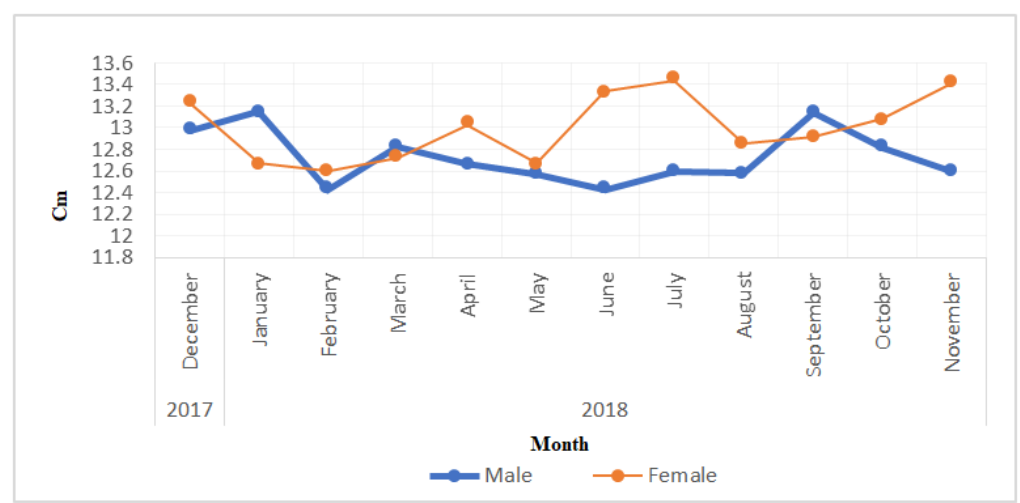

Fig. 2. Average Carapace Width 


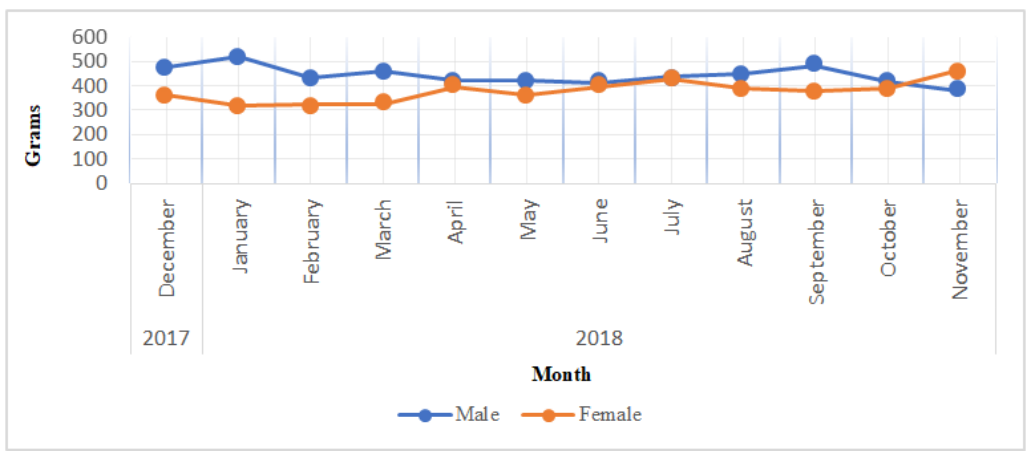

c) Proportion of Juvenile Fish Captured

Fig. 3. Average of Weight

Juvenile is a measure of a stage in the growth of fish that has not yet entered the mature size category. The unit used for the indicator of the proportion of juvenile fish caught is (tonnes, $\mathrm{kg}, \%$ proportion) which is compared to the overall fish biomass of the catch for each fishing gear in the particular observed waters. The existence of yuwana is also very important to ensure that recruitment (entry of young individuals into the population) will occur [7].

Determination of the level of gonad maturity (TKG) in female mangrove crabs can be done by two examinations, namely morphological and biological examinations. Morphological observations were made by looking at the changes in size and color that were seen in the lower part of the abdomen.

Based on the measurement results of the maturity level of crab gonads from 1208 samples, it was obtained TKG I (20\%), TKG II (16\%), TKG III (30\%) and TKG IV (34\%). The data on the percentage of female crab TKG can be seen in Figure 4. TKG IV is said to be perfectly ripe and ready to be spawned. The morphological characteristics of TKG IV egg granules are getting bigger and clearer in orange color and can be separated easily because the oil layer has decreased. The histological characteristics of the egg granules are larger than TKG III and the oil layer covers the entire cytoplasm.

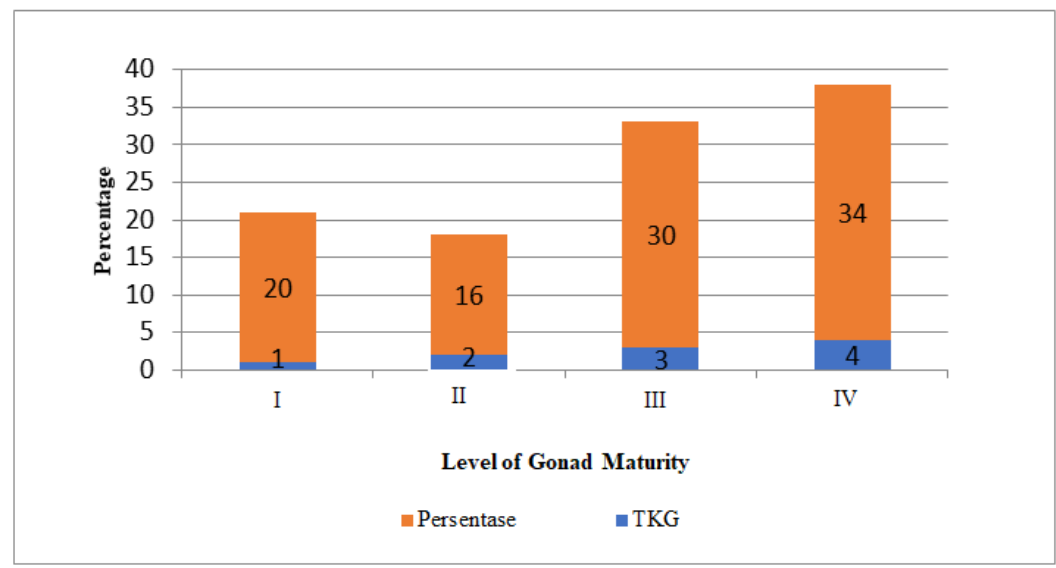

Fig. 4. Level of Gonad Maturity 
Based on the description above, the catched Juvenile Proportion indicator is categorized as good and given a score of 3 , which is a little $(<30 \%)$.

\section{d) Composition of Catch Species}

Species composition is a measure of the biomass of a particular species that is the target of fishing and species that are not the target of catching the total catch from a fishing gear [7]. The types of fishing gear used are square and round traps with a mesh opening of 1.5 inch and a mouth opening of $40 \mathrm{~cm}$. Based on the results of interviews conducted, the types of crab caught were Scylla traguebarica, Scylla olivacea and Scylla sp. Based on the description above, the Catch Species Composition indicator is categorized as good and is given a score of 3 , namely the proportion of targets is more (> $31 \%$ of the total volume).

\section{e) Range Collapse Fish Resources}

Range collapse is a common phenomenon in fish stocks when the fish stock is under overfishing [7]. Based on the results of interviews with a total of 63 respondents, 44 respondents $(70 \%)$ said there was a change, 16 respondents $(25 \%)$ did not provide an opinion and 3 respondents $(5 \%)$ said that the resources were fixed in relation to the use of crab resources in the last 10 years. The contributing factor is that the catch is decreasing due to the increasing number of crab fishermen, related to the problem of paying for fishing locations and customary rules.

Based on the description above, the indicator for Range Collapse of Fish Resources, which is that there has been no decline in crab stock in the last five years, can be given a score of 2 , which is relatively constant, depending on the target species.Regarding the distance to the fishing location, generally the respondents said that the fishing ground was relatively fixed, depending on the target species so that this criterion was given a score of 3 .

\section{f) Endangered, Threatened, and Protected (ETP) Species}

Endangered (EN) or Genting species is a category that is applied to taxons that are not included in Critically endangered but are at a very high risk of extinction in nature and are included in the category of Extinct in the Wild if in the near future significant protective measures are not taken. Threatened species, namely species that are not included in the Critically endangered, Endangered, or Vulnerable categories, but have a great chance, or at any time can be categorized as Threatened species. Meanwhile, protected species are species which, due to their existence in nature, are critical or endangered, they are protected by law in terms of their utilization [7].

From the results of interviews with a total of 63 respondents in Teluk Bintuni, no Endangered, Threatened and Protected (ETP) species were caught. Based on the description above, the indicators for Endangered, Threatened, and Protected (ETP) Species are categorized as given a score of 3, namely no ETP individuals were caught. But fishermen still use ETP species, namely sharks, which are used as bait.

\subsection{Aggregate}

The results of the assessment on the Fish Resource Domain show that the crab fishery management in Teluk Bintuni Regency is in good condition, with a mean value of 2.5. The 
results of the assessment on each indicator of the Fish Resource Domain can be seen in Table 2 below.

Table 2. Flag Model Analysis of Six Fish Resource Domain Indicators

\begin{tabular}{lcl}
\hline Indicator & Score & Des cription \\
\hline 1. Standart CpUE & 2 & Apllying EAFM \\
2. Trends in fish size & 2 & Apllying EAFM \\
3. Proportion of yuwana fish caught & 3 & Excellent to aplly EAFM \\
4. Composition of catch species & 3 & Excellent to aplly EAFM \\
5. "Range Collapse" fish resources & 2.5 & Good to aplly EAFM \\
6. ETP species & 3 & Excellent to aplly EAFM \\
\hline
\end{tabular}

Standard CPUE indicator, Crab Size Trends, Proportion of Juvenile fish caught, has a value of 2 or based on the analysis of the yellow flag which is medium status. The indicator "Range Collaps e" of fish resources is worth 2.5 or based on green color analysis, which is good status. The indicator for the composition of the catch species and the ETP species is worth 3 or based on the analysis of the green flag, which is good status, as shown in Figure 5.

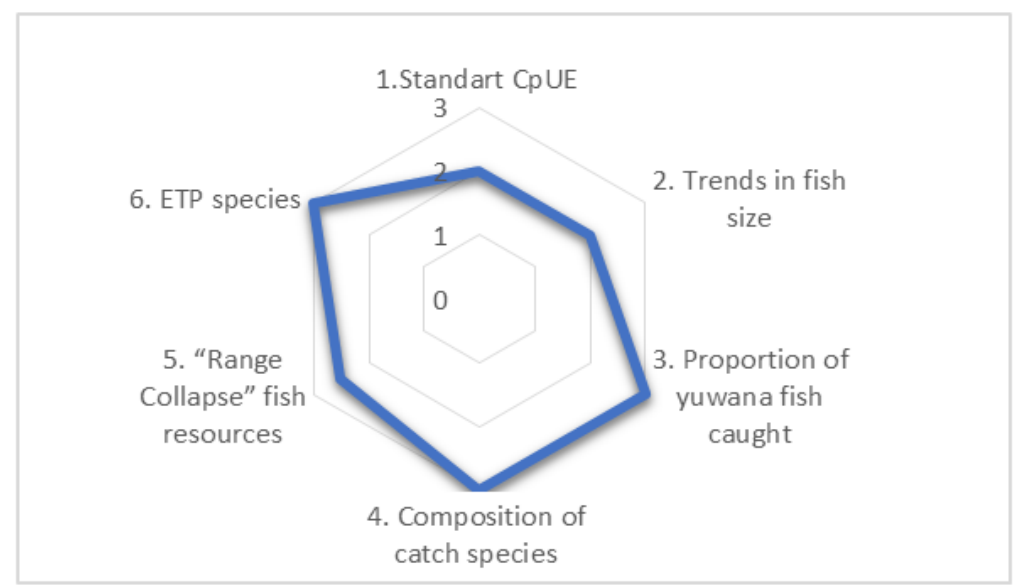

Fig. 5. Fish Resource Domain Kite Graph

\subsection{Recommendation}

a. CPUE. The steps that need to be taken to keep standard CPUE in good status are periodic data collection of catch production at each landing site to determine the standard CPUE trend, determination of the fishing season index so that it can be used in determining the right time to conduct crab fishing operations and limitation on the number of fishing gear and the arrangement of fishing areas.

b. Indicator of Trends in Fish Size. The steps that need to be taken to improve the Trends in Fish Size so that they have a good status are dissemination and FGD (Discussion Group Forum) among stakeholders (DKP and other related institutions, both formal and nonformal) and training for fishermen on the rules for catching crab sizes and implementing regulations and monitoring the size of crabs caught at every fish landing.

c. Proportion Indicator of Juvenile Fish Caught. The steps that need to be done are research development on the size of the first ripe gonads that can be caught crabs and disseminating 
research results on crabs that can be caught based on the size of the gonads that are first ripe.

d. Catch Species Composition Indicators. The steps that need to be taken in order to maintain a good status of the Catched Species Composition are maintain the size and type of fishing gear used to catch crabs through policies / regulations.

e. Range Collapse Indicator for Fish Resources. The steps that need to be taken to keep the Fish Resource Range Collapse in good status are making regulations on control of fishing efforts and fishing grounds that accommodate customary law.

f. ETP Species Indicator. The steps that need to be taken to improve the ETP species to their good status is socialization to the community by providing an understanding of the ETP species.

\section{Conclusion}

The results of the assessment on the Fish Resource Domain indicate that the management of crab fisheries in Teluk Bintuni Regency is in good condition, with a mean value of 2.5.

\section{References}

[1] P. Geografi, "Gambaran Umum Dan Kondisi Wilayah Kabupaten Teluk Bintuni," 2002, [Online].Available: http://sippa.ciptakarya.pu.go.id/sippa_online/ws_file/dokumen/rpi2jm/DOCRPIJM_15 03898863Bab_II_GAMBARAN_UMUM.pdf.

[2] M. Y. Franklyn Hoek, Abu Darda Razak, Misbah Sururi1, "Distribusi Frekuensi Ukuran Lebar Karapas dan Berat Kepiting Bakau (Scylla serrataforskal) dengan Alat Tangkap Bubu Lipat Di Perairan Kabupaten Teluk Bintuni, Papua Barat Franklyn,” J. Airaha, vol. 4, no. 2, pp. 57-64, 2015, [Online]. Available: https://jurnalairaha.org/index.php/airaha/article/view/35/20.

[3] M. Mulyana, "Valuation of EAFM Indicators in Raja ampat and Aru Islands Districts," J. Mina Sains, vol. 4, no. 1, p. 1, 2018, doi: 10.30997/jms.v4i1.1266.

[4] N. I. Wahid, R. Noviyanti, and E. Riani, "Pengelolaan Perikanan Pelagis Besar Dengan Pendekatan Ekosistem Di Kabupaten Mamuju Utara Sulawesi Barat," J. Mat. Sains dan Teknol., vol. 20, no. 1, pp. 30-44, 2019, doi: 10.33830/jmst.v20i1.86.2019.

[5] A. N. Agus Apun Budhiman, Hary Christijanto, Siti Kamarijah, Ganef Hari Budoyo, Imam Musthofa, Abdullah Habibi, Luky Adrianto, Yusli Wardiatno, Handoko Adi Susanto, Auhadillah Azizy, Arif Trihandoyo, Pendekatan Ekosistem dalam Pengelolaan Perikanan di Indonesia. Direktorat Sumberdaya Ikan - Direktorat Jenderal Perikanan Tangkap - Kementerian Kelautan dan Perikanan, WWF-Indonesia dan Pusat Kajian Sumberdaya Pesisir dan Lautan - Institut Pertanian Bogor, 2011.

[6] A. C. Morgan and G. H. Burgess, "Fishery-dependent sampling: Total catch, effort and catch composition.," Elasmobranch Fish. Manag. Tech., pp. 241-264, 2004.

[7] Y. Adrianto L, Habibi A, Fahrudin A, Azizy A, Susanto HA, Musthofa I, Kamal MM, Wisudo SH, Wardiatno Y, Raharjo P, Nasution Z, "Penilaian Indikator untuk Pengelolaan Perikanan dengan Pendekatan Ekosistem,” pp. 1-201, 2014. 
